\title{
SUSTAINABILITY AND LOCAL ECONOMIC DEVELOPMENT IN CANADA AND THE UNITED STATES*
}

\author{
L. REESE ${ }^{1} \&$ G. SANDS ${ }^{2}$ \\ ${ }^{1}$ Global Urban Studies, Michigan State University, East Lansing, MI, USA. \\ ${ }^{2}$ Urban Planning, Wayne State University, Detroit, MI, USA.
}

\begin{abstract}
This article provides a description, summary, and analysis of representative efforts to deal with the challenges to sustainability that result from the predominant patterns of land use in the metropolitan areas of North America. Two broad categories of public policies are considered: management and control of peripheral growth and revitalization efforts to improve the competitiveness of older urban areas. Metropolitan efforts to achieve more sustainable development through management of new development tend to rely more on voluntary agreements that preserve local government autonomy than on regional collaborations. The regional approaches that have been implemented to date have had only limited effectiveness. Efforts to make older communities more competitive with greenfield development have focused on downtown revitalization, industrial location incentives, business incubators, and neighborhood revitalization. While most of these efforts are carried out by state and local governments, faith-based organizations have come to play an increasingly important role. Downtown and industrial revitalization initiatives frequently provide only limited benefits despite their high public cost. Business incubators and neighborhood improvement efforts appear to be more cost effective strategies. On balance, the lack of political will and the preferences of households and businesses for new, low-density developments are likely to continue to foster unsustainable forms of urban development in most North American urban areas. Keywords: business incubators, downtown revitalization, growth management, industrial location incentives, regional planning, tax base sharing, tax increment financing, urban growth boundaries.
\end{abstract}

\section{INTRODUCTION}

Urban areas throughout North America have historically assigned low priority to issues of sustainability. In part, this is the result of the relative abundance of land and other natural resources. Few North American metropolitan areas are physically constrained by barriers that limit their continued outward diffusion. Even where natural resources, especially water, are limited, engineering solutions have allowed urban areas to grow. The result has been a dominant pattern of 'sprawl' in urban areas throughout North America. This low-density, discontinuous development consumes excessive amounts of land and natural resources, impacts environmentally sensitive areas, and is difficult to service. Because the marginal cost of new development is below the average cost, the long-run sustainability of much of suburban development is questionable [1,2].

The predominant forms of peripheral development also have detrimental impacts on the viability of central cities. As new development occurs at the urban fringe, core areas of many cities erode. Population, employment, and investment have shifted outwards, leaving behind declining neighbourhoods, abandoned factories, and desolate commercial strips. The central business districts of most North American cities have lost retail functions as well as much of their office employment base [3]. As businesses and higher-income residents have departed, a downward spiral has resulted where municipal tax burdens grow as tax bases erode and the demands for services from low-income residents increase. High taxes and poor public services create barriers to attraction or retention of businesses and residents in central cities, thus perpetuating a vicious cycle of decline [4].

*An earlier version of this paper was presented at the Sustainable Planning Conference, Bologna, September 2005. 


\section{OBJECTIVE}

Based on a meta-analysis of extant literature and research, this article provides a description, summary, and analysis of representative efforts to deal with the challenges to sustainability presented by the patterns of urban land use and sprawl in cities in North America. The overall objective is to provide a sense of the challenges to, and effectiveness of, a number of specific sustainable local development policies. The findings provide a sense of how such policies are designed and implemented and identify issues that should be considered before such policies are emulated to increase sustainability in other contexts.

There are two broad categories of efforts to address urban sprawl and the attendant sustainability problems: controlling new peripheral development and revitalizing older urban areas to make them more competitive. Common strategies for controlling or mitigating the negative effects of new development include efforts to increase intergovernmental cooperation, enhance coordinated planning, and rationalize economic development efforts that typically take the form of changes or modifications to the urban governance structure [5,6]. Structural changes from the most minor to the most radical are explored in the section on urban governance. Significant structural change is absent in most urban areas due to political constraints [5-7]; however, most cities implement economic revitalization policies on an individual basis. Such strategies are typically directed at city centre, industrial, or neighbourhood revitalization $[8,9]$. Common local economic development policies in each of these areas are explored to assess their impact on the goals of sustainability identified in the next section.

\subsection{Sustainability and local economic revitalization}

The adverse impacts of urban sprawl are many and include redundant and deteriorating infrastructure, environmental and resource degradation, duplication and inefficiencies in service provision, and inequities among municipal fortunes [10]. All of these outcomes create an urban growth pattern that is simply not sustainable over the longer term - economically, environmentally, or socially [11]. While early discussions of sustainability focused on environmental issues, most economic development scholars agree that it has a broader meaning, one more directly reflecting concerns about land use, resources, and urban planning. The elasticity in the term 'sustainable development' has caused it to become 'one of the most overused and least understood terms in our contemporary vocabulary' [11].

Originally, 'sustainable development' focused on the relationship, often viewed as mutually exclusive, between economic values and social and environmental values [12]. Or stated differently, 'the origins of the term sustainable development lie in the realization that many efforts at economic development in less developed regions of the world have had serious adverse environmental effects on the countries they were trying to help' [13]. According to Colgan [13], the most commonly quoted definition of sustainable development is development that 'meets the needs of the present without compromising the ability of future generations to meet their own needs' [14]. Expanded to city regions, the term focuses on the trade-offs between economic growth (often represented by land use patterns such as sprawl) and impacts on the environment.

More recently, however, 'sustainable development' has come to mean the explicit consideration of the social and environmental impacts of economic development, and a concomitant effort to engage in an integrated approach to planning and policy that focuses on achieving success on all three fronts [2]. Thus, sustainable economic development is 'strategic investment in government projects and programs to restore and develop natural and social capital ... leading to increased economic capital gains' [11], making regional systems 'more adaptive and innovative and thus sustainable' [2]. Ultimately, a sustainable metropolitan system is 'one that shows a high degree of adaptability to global 


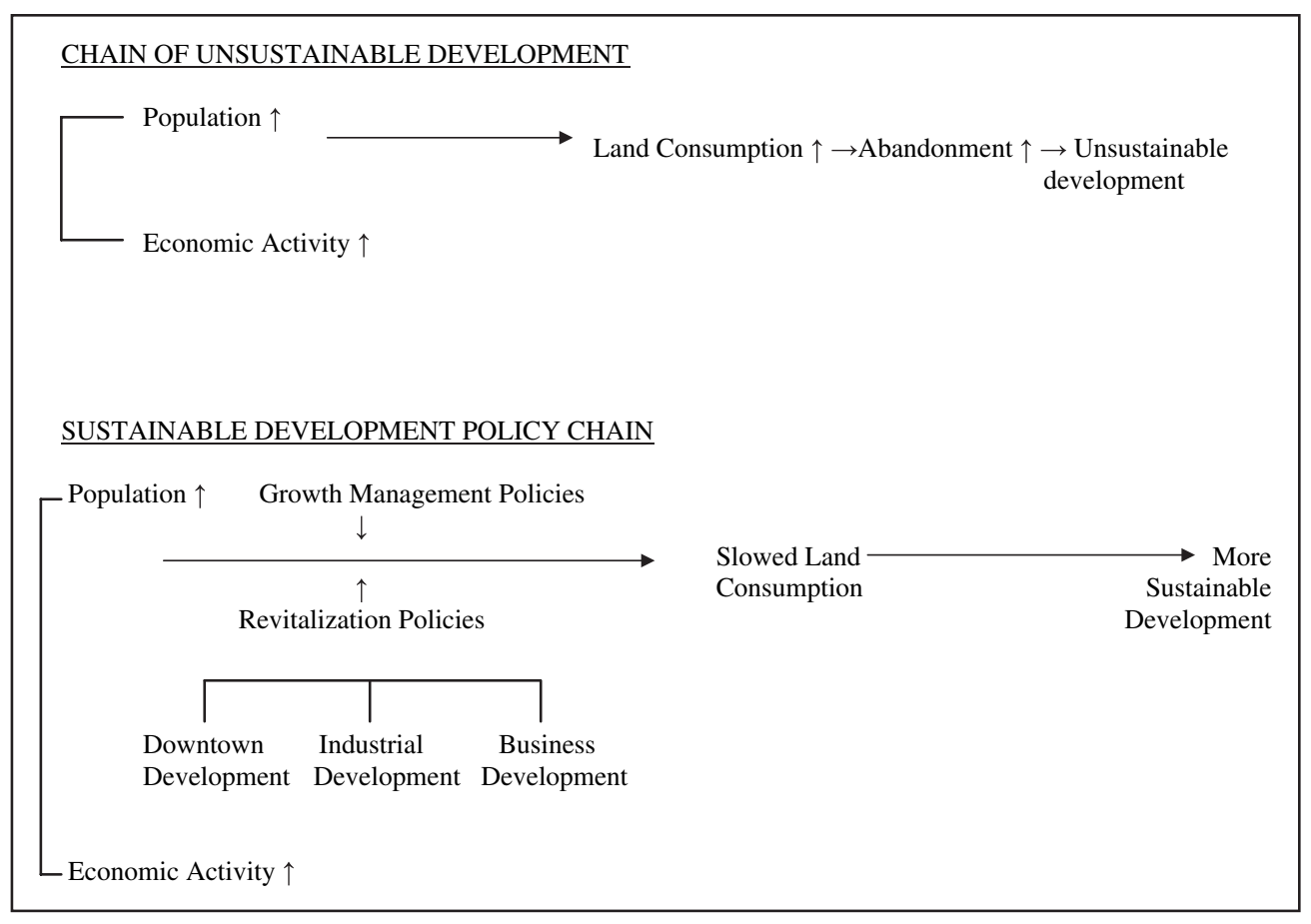

Figure 1: Sustainable economic development models.

and technological change and in which the economy moves to higher levels of productivity rather than stagnating or collapsing into chaos' [2]. In short, sustainable economic development as used here means local and regional economic development policies that build social as well as economic capital, enhance quality of life for communities, do not exacerbate stress on the local environment, and lead to more viable and flexible local economies in the future.

Figure 1 illustrates two models of urban growth - one sustainable, the other not. In the unsustainable and most typical pattern particularly in the US, population growth and economic activity lead to increased land consumption at the periphery with concomitant abandonment in older centre cities. This leads to the overall pattern of urban sprawl that is unsustainable environmentally, economically, and socially. The second path incorporates efforts to enhance sustainable development. Here population and economic growth are accompanied by explicit governmental efforts at growth management, cooperation, and governance change as well as policies to revitalize central cities (such as the downtown redevelopment, tax incentive, incubator, and faith-based efforts described here). These efforts to mitigate sprawl and revitalize urban cores should lead to more sustainable economies and social systems over the long term.

\section{MANAGING PERIPHERAL GROWTH THROUGH GOVERNANCE}

Although there is growing recognition that current development patterns in most North American metropolitan areas are not sustainable $[4,10]$, efforts to control or better manage peripheral growth have had only limited success $[15,16]$. A fragmented local government structure (many, independent municipalities within the same urban region), strong traditions of property rights, preference for lowdensity development, and lack of clear policy direction from senior levels of government make efforts 
\begin{tabular}{|lr|}
\hline Complete Fragmentation & Complete Integration \\
$*$ Home rule *COGs *Inter-local agreements * Lakewood Plan *Tax base share ${ }^{*}$ Growth Boundaries *Two-tier *Consolidation
\end{tabular}

Figure 2: Spectrum of cooperation.

to plan and manage growth for sustainability almost impossible. While Canadian metropolitan areas have fared somewhat better in terms of sustainability, they too are coming under increasing pressure to address peripheral growth and local sustainability [17-20].

Approaches to managing growth and preventing urban sprawl include coordinated planning or governance structures that emphasize regional issues, rather than the economic fortunes of single communities. Metropolitan-wide planning and governance structures may take many forms, creating a spectrum of cooperation from minimal, informal initiatives to complete structural change in the form of consolidation of local government units. Figure 2 illustrates the range of cooperative or regional approaches used in North America.

The fragmented approaches on the left side of the figure generally predominate. Home rule is the most common relationship between states and local governments in the US, although not in most provinces in Canada. Municipal units are allowed, under state constitutions or statutes, to develop their own charters with few limitations, have wide latitude in policy and service delivery decisions, and are free to cooperate (or not) with other local units. During the 1960s the US federal government encouraged local units to cooperate through entities known as Councils of Government (COGs). These are voluntary and typically lack the ability to 'force' local participants into cooperative activities. COGs were designed to oversee service functions where cooperation was paramount or where significant economies of scale would accrue with lower service costs at high levels of production. As such, COGs typically engage in regional planning, transportation, road infrastructure, and economic development [21, 22].

Voluntary agreements between local units of government are also widespread, albeit usually for limited purposes, and may provide a source of optimism for the growth of regional cooperative solutions to sprawl. The 'Lakewood Plan', named for the city of Lakewood, California, is an extreme but relatively rare formalized example of such inter-local cooperation where an individual municipality purchases all of it services from a county government (in Lakewood's case, Los Angeles County) lowering costs through economies of scale [23, and Lakewood website: www.lakewoodcity.org/info/ 50_new/lakewood_plan.asp]. More common are situations where local governments contract with neighbouring communities or the county for particular services or packages of services. Also common are voluntary agreements among municipalities that include cooperative purchasing of a range of items from office supplies to fire trucks, emergency back-up arrangements, and transportation services $[24,25]$.

Tax base sharing arrangements and complete consolidation of local units of government represent more radical but probably more sustainable efforts to ensure coordinated planning and minimize the costly and environmentally damaging effects of uncontrolled peripheral urban growth. Under the former (present in the Minneapolis/St. Paul Minnesota metropolitan area), municipal units contribute a portion of their tax base growth to a common pool which is then reallocated among participants based on need and economic stress. Such arrangements reduce the unhealthy competition for economic development that often drives sprawl, and produces fiscal inequities among local units dependent on local property value for survival, although the equalization effects seem to lessen over time [26].

Inspired by the London greenbelt established after the Second World War, urban growth boundaries attempt to establish a finite edge to the outward spread of urban development. The boundaries may 
be permanent as in the case of Ottawa where the federal government has purchased lands around the national capital. Portland Oregon's urban growth boundary is more flexible with periodic reviews to ensure that there is ample land available for anticipated growth. Proponents of the Portland growth boundary argue that it has contributed to strengthening both the downtown core and neighbourhoods by encouraging higher densities [27]. Critics, however, maintain that the boundary has caused high land and housing prices [15]. While the empirical evidence on this question is limited, it is clear that, to be effective, urban growth boundaries require the cooperation of all municipalities in the metropolitan area. Otherwise, the establishment of the growth limit will simply encourage more development at lower densities further from the core [16].

Two-tier systems, while innovative and logical in design, have not withstood the test of time as measures to increase sustainability [28-30]. Such systems, most prominently tried in Toronto Ontario and Miami Florida, were comprised of two levels of urban government - the original local unit and a regional level - similar to a federated system like the Canadian and US national governments. Local units kept many services - schools and parks - while services subject to economies of scale - planning, transportation - were provided at the regional level. While judged successful by many scholars and pundits, the Metropolitan Toronto system was abolished in favour of complete consolidation due to political pressures and concerns about continuing sprawl [31]. The Miami two-tier system disintegrated under the weight of infighting and other political concerns [32]. Portland Oregon and Vancouver British Columbia have the only remaining elected two-tier metropolitan government organizations.

Complete consolidation of local units is rare in the US but more common in Canada. It has been touted as a way to increase coordinated planning, reduce sprawl, increase economic development, achieve lower cost services through economies of scale and reduction in redundancies, and even reduce the numbers (and hence cost) of multiple local officials [33]. Over the past four decades, US voters have rejected three-quarters of all city/county referenda [34]. During the 1980s only 25 referenda were put forth to approve consolidations but during the first six years of the 1990s there were 18; in 1996 alone 12 communities conducted consolidation studies [34]. Traditionally, consolidations in the US have occurred in metropolitan areas of 150,000-800,000 [35], but more recent consolidations have taken place in areas under 100,000 [36].

The experience with consolidation and other forms of regional governance has been much more extensive in Canada and has resulted in lower levels of urban sprawl and governmental fragmentation than in the US [37]. There was a great deal of consolidation activity in Canada just after the First World War but it then died down considerably. With financial pressures in the 1990s, consolidation became more attractive and prompted greater attention. The extent of governmental reorganizations has varied by province, with Ontario quite active, although policies in the 1970s favoured regional solutions rather than outright consolidations. This has changed in recent years, however; from 1975 to 1992 there were no consolidations in Ontario and then five within a two-year period in the mid-1990s [38].

Studies evaluating the results of consolidations have been mixed although most agree that more coordinated, long-range metropolitan planning results and that inequities among local units are reduced [39-41]. However, it is still unclear whether this type of radical structural change really reduces sprawl, increases economic development, and serves to reduce the costs of service provision, thus making local entities more sustainable over the long term [42-45].

For the most part, even where the more extreme forms of intergovernmental cooperation are in place, the results are often quite limited with respect to changing the overall pattern of development. Portland and a number of Canadian metropolitan areas have experienced increases in density in response to limitations imposed on peripheral growth. In some instances, notably the Washington DC metropolitan area, significant investments in rail mass transit have had visible impacts on development 
in older suburbs, arguably reducing peripheral growth [46]. Overall, it appears that voluntary, less radical efforts to increase cooperation - those on the left in Fig. 2] - are the most viable. However, they are also the least likely to lead to significant long-term change in urban growth patterns.

\section{REVITALIZATION STRATEGIES}

Although national and state/provincial governments have provided few effective tools or incentives to curb peripheral growth and improve sustainability in urban areas, senior levels of government have provided local jurisdictions with a variety of tools intended to make central cities and older suburbs more competitive [8]. While these initiatives vary considerably across jurisdictions, they typically seek to level the playing field between the redevelopment of older communities and growth at the periphery through a variety of market interventions. The results of these initiatives have been mixed at best [47]. And, it has been difficult to achieve balance in the benefits of such efforts, particularly between the public (emphasizing older downtowns) and private (emphasizing business development) benefits. Three quite different revitalization strategies are highlighted - city centre, industrial, and neighbourhood - representing often opposing activities given limited local resources for redevelopment and competing uses of public investment.

\subsection{City centre revitalization}

The dominant role of the city centre has continued to erode in many urban areas. For small and medium sized municipalities, with populations between 75,000 and 350,000, efforts to sustain core areas have proven difficult [48]. Urban areas in this size range typically have a downtown business district (as opposed to a more limited main street) but are unlikely to have extensive public transit systems [3]. Nevertheless, city centres are still regarded by many as important parts of the metropolitan area [49]. Even those cores with little retail activity may continue to be major employment centres, with government, financial concerns, and utilities remaining in central locations [50]. The city centre represents a substantial investment in infrastructure, both public and private. In many communities, the city core constitutes a major portion of the municipal property tax base and is the focus of transportation networks. It may also have historic character and even absent significant historic attributes, representing the symbolic identity of a city, particularly as a measure of the value placed on public space and investment. As a result, communities continue to pursue city centre revitalization and seek new strategies for their efforts [51, 52].

City centre revitalization has taken a number of forms, with dominant strategies changing over time. Initial efforts to replace public mass transit with freeways and parking garages were followed by the development of suburban style shopping malls. Neither of these strategies has been particularly successful, however, and have often proved inimical to the sustainability of downtown cores as they shift retail and customers to the periphery and standardize commercial landscapes, creating what some US observers label 'generica' [53]. More recently, revitalization strategies have gone in the opposite direction, focusing on increasing downtown population, niche market retailing, and urban entertainment, including convention centres, sports venues, and casinos, with mixed results [9].

A recent survey of city planners and other urban professionals asked respondents to identify those features of North American city centres that led them to consider an area to be successful [54]. The most important were a pedestrian friendly environment, with people on the streets; active, streetoriented retail; cultural events; and employment. Green spaces, civic events, tourist activities, historic character, strong neighbourhoods, and architectural quality were also considered to be important. In addition, successful city centres were often found in state or provincial capitals, on waterfronts, and where a large university was located close to the core. Although many of these features are beyond the 
control of local economic development efforts, planning can contribute to the vitality of city centres by emphasizing the distinct sense of place that core areas represent and by providing infrastructure and development regulations that support a human scale environment.

Recent research on successful downtown revitalization has recommended a number of ways to revitalize core areas with a particular focus on smaller and mid-size cities that represent most urbanized areas in North America [53]:

- Pedestrian friendly streets: The most basic strategy for a successful downtown is the creation of attractive pedestrian streets, typically providing wide sidewalks, distinctive paving, benches, street lights, banners, and flowers. These features identify the city centre as a special place, distinct from the rest of the city.

- Heritage promotion and tourism: Successful core areas actively promote heritage properties as important elements of the city centre. These efforts not only provide potential tourist attractions but also help ensure the distinctive character of the downtown, setting it off from homogenized suburban alternatives [3].

- Residential: Policies to increase the residential component of the city centre are a means to extend downtown activity beyond the nine-to-five workweek, increasing both market potential and foot traffic [55, 56].

- Densification: The decline of many central business districts has resulted in the proliferation of abandoned buildings, vacant store fronts, and surface parking lots, all contributing to a negative image of the core. Viable activities and uses become isolated. Restoring the urban fabric through development regulations, design controls, and heritage preservation can help restore continuity among key activities.

- Regional planning and development strategies: The health of the core area continues to be influenced by metropolitan development trends. Peripheral commercial development located near highway interchanges competes with the city centre [57]. These centrifugal forces are difficult to counter in the absence of strong regional planning or regional government [10].

While the foregoing foci are necessary to revitalize downtowns, evidence suggests that they are far from sufficient in assuring success. Such activities must be combined with and enhanced by the following more basic attitudes and relationships [53]:

- Perceptions matter: The image of the core is as important as the reality. The reputation of a city and its core area is complex and unlikely to be formed based on a single attribute or revitalization activity. There may also be a significant time lag in any change in perceptions, so that current circumstances may not adequately reflect the basis for reputation. Moreover, since a struggling city centre is likely to adopt programmes and policies to emulate more successful ones, some degree of convergence is to be expected.

- Priorities matter: The city centre is likely to become, or remain, healthy only if it continues to be a priority for the community. Successful city centres will not often occur by chance. They must receive high levels of attention and investment to ensure continued prosperity.

- Partnerships matter: No one organization, or type of organization, can single-handedly bring about the revitalization of older urban core areas. Efforts to revitalize the city centre are not just the domain of the public sector. Government initiatives must be undertaken in cooperation with the private sector, civic leadership, as well as the non-profit community.

- Planning matters: Local planning efforts matter at two important levels. The first is that planning can provide the basis for articulating community goals and priorities for the city centre. Basic planning functions such as visioning, strategic planning, development of alternative scenarios, coalition building, and communication are essential to the achievement of a successful revitalization 
programme. Professional planning also plays an important role in implementation, in areas ranging from goal setting to design review. A great deal will depend on the tactics employed in implementation.

\subsection{Industrial revitalization}

What the foregoing revitalization strategies have in common is their focus on rebuilding public space and benefits that eventually accrue to the larger community through a more viable and sustainable urban core. To be sure, commercial and retail interests also benefit but these efforts focus much more directly on the larger community good. Efforts at industrial revitalization focus on private benefits and investment that are expected to 'trickle down' to community residents in the form of jobs and an increased tax base to support public services. Most states allow municipalities to offer businesses significant reductions in property taxes in exchange for commitments to invest or remain in the community and provide jobs for local residents [8]. Although the use of tax abatements is widespread, it is also hotly debated by scholars and community leaders [47, 58]. Opponents argue that they are not effective, are too costly to communities that can least afford them, and reward businesses for doing what they would likely have done anyway. Proponents argue that no revenue is lost because without the abatement no investment would be made, and that for older cities, tax benefits are essential to remain competitive with peripheral suburban locations in retaining employment and tax base, let alone in spurring growth $[58,59]$.

It should be noted that all of this research is on tax abatement policies in the US - many Canadian provinces do not allow cities to use abatements although they can be granted at the provincial level. Such provincial control allows regulation and balancing of abatement use among cities and regions; it also appears to reduce inter-city competition for development and increase the use of economic development activities that are more creative and entrepreneurial and thus have a better chance of creating sustainable development $[8,9]$. This same result appears to occur in the few US states that prohibit tax abatements by cities [60].

The Public Act 198 tax abatement programme in the state of Michigan provides an example of the sustainability implications of a commonly used economic development tool, the abatement of municipal taxes. PA 198 of 1974 permits local governments to reduce property tax liability for new investment in industrial plant and equipment; new facilities are taxed at half the prevailing rate. For rehabilitated facilities, new investment is exempt from taxation and the taxable value of the existing facility is frozen at the pre-rehabilitation level for up to twelve years encouraging firms to stay in place. Since its inception, PA 198 has been an extremely popular programme; some 660 of Michigan's 1,777 local governments have granted industrial tax abatements; only four of 83 counties across the state lack participating jurisdictions. More than 15,000 Industrial Facilities Tax Abatements were granted between 1974 and 1998. These tax exemptions have provided for replacement of obsolete facilities rather than new construction, and retention of jobs not creation of new employment opportunities. From 1995 to 1998, almost 85\% of the \$19 billion in PA 198 investments represented abated personal property (equipment) [61].

Concerns about the impacts of tax incentives on sustainability and inter-city equity appear well founded based on recent research on the effects of tax abatements in Michigan [47]. For example, abatement use does not appear to favour distressed areas and, if per capita abatements are considered, generally healthy exurbs have offered more abatements than central cities and inner ring suburbs. While central cities appear to have done relatively well in the number of jobs retained and created, they are also likely to have a higher percentage of abated jobs relative to the total workforce. Investment patterns, particularly new development and new jobs, favour exurban areas. Thus, it can be concluded 
that use of abatements by exurbs is supporting the movement of business, people, and infrastructure investment further from existing central cities, contributing to sprawl rather than sustainable urban redevelopment. When investment estimates are considered as forgone tax revenue, it is clear that distressed areas are spending more to create or retain each job. And, central cities are having to abate or 'buy' larger proportions of jobs relative to their workforce than suburban or exurban communities in the same metropolitan areas [47].

Community economic health in municipalities using abatements heavily has worsened relative to others; again forgone tax revenue is greater in these communities but it has not increased sustainable wealth. Although it is possible that these cities would have been far worse off had they not offered abatements at all, it is clear that, even given abatements, they are losing ground and in some instances quite significantly. On the other hand, occasional use of abatements appears to be effective in stemming economic loss. While it cannot be concluded that prohibiting abatements causes the greatest economic growth, it is clear that the absence of abatements has not hindered growth trends in those communities limiting abatements [47].

The fact that exurban communities exhibit the highest levels of growth in population, tax base, and income relative to their central cities and inner ring suburbs suggests that fiscal heath gaps among municipalities are widening [47]. That tax abatement use is widespread among communities of all types indicates that it is exacerbating inequities among jurisdictions rather than ameliorating them.

Evaluations of the effects of tax abatement programmes such as PA 198 in Michigan have been somewhat mixed, but the preponderance of evidence has suggested that tax abatements:

- are only effective at the margins in business location decisions;

- only serve to increase the 'zero sum' aspect of local development because they pit one community against another;

- tend to redistribute public sector revenues to private sector interests;

- are used primarily by healthy cities that can 'afford' to forgo the potential tax revenues; and

- tend not to produce jobs and tax base benefits commensurate with the loss of local revenues [58, 62-65].

Several policy recommendations can be posited to encourage abatement use in ways that do not increase inequities and hence are more likely to promote sustainability [47]. These include:

- Limit tax abatements to distressed areas, particularly prohibiting the use of abatements in exurban and rural areas except in exceptional circumstances.

- Limit or cap the number of abatements that can be given by an individual municipality in a particular time period.

- Limit the dollar value of investment that can be abated, particularly for distressed communities.

- Favour applications for abatements that involve new jobs and real property investment, particularly in already urbanized areas.

- Require the collection of outcome data, confirming investment and job creation levels.

- Require cost/benefit assessments as part of the abatement application process, insuring a consideration of forgone revenues per job retained and created.

- Increase outreach efforts to educate local officials and citizens about the impacts of tax abatements.

\subsection{Community and neighbourhood revitalization}

While downtown and industrial revitalization strategies are common across North America, there have also been relatively widespread efforts to enhance sustainability and ameliorate the effects of sprawling growth patterns through more direct investment in urban communities and neighbourhoods. 
Three examples of such direct neighbourhood investment are described here: business incubators, faith-based development efforts, and neighbourhood tax increment finance areas. These three examples have been selected because two are innovative strategies - one (business incubators) typically implemented by the public sector and the other (faith-based efforts) by non-profit organizations and the third is more traditional but widely utilized throughout North America $[8,9]$.

\subsubsection{Business incubators}

Small business incubators have a long history as economic development tools, beginning in the UK in the early 1970s with artist cooperatives, often located in historic buildings. In the US, incubators have been stimulated by desires to redevelop blighted inner city neighbourhoods, grant programmes of the National Science Foundation promoting university/entrepreneurial partnerships to foster innovation, and groups of entrepreneurs attempting to extend their expertise to other small business owners [66]. Beginning on a small scale - about 40 registered business incubators in 1985 and growing to at least 600 in 1995 - the attractions of incubators as a sustainable development tool are many [67].

The interest in incubators stems from the role small business plays in the North American economy. In 1993, 54\% of US employment was in firms with less than 500 employees. Further, small firms have been credited with $55 \%$ of all innovations in products and services. However, juxtaposed with these contributions is the fact that $53 \%$ of all small businesses fail within their first four years of operation [68]. These data have several implications for community development: small businesses are desirable because they can employ local residents and often operate in areas of technological innovation, but significant efforts must be made to ensure that the businesses are not created only to fail. Business incubators address these realities.

Typically a small business incubator begins with a facility/building offering a common location for new firms. The incubator offers below-market rents and an array of support services designed to meet the needs of small start-up firms often owned by inexperienced or first-time entrepreneurs. Tangible services often include shared equipment, computing and secretarial services, assistance in business and marketing plans, legal services, joint promotion, and the like. Assistance in gaining start-up capital is often a critical component of incubator projects. Intangible benefits accrue from the ability of business owners to act as a support system for each other although that can also turn into tangible benefits in the form of contracting among incubator firms. The goal is for new businesses to start in the incubator and then move out when they grow too large or are stable enough to operate without the special support provided by the incubator.

Incubators have been financed through cooperative private efforts but have tended to get most of their support from government financing, primarily at the local or regional level. Research has suggested that incubators have been successful in stabilizing small businesses, prompting limited job generation, and increasing sales among incubated firms for relatively small investments of public dollars [68-70]. Indeed, it has been suggested that the cost per job created for incubated jobs is about $\$ 6,580$ while the cost per job for other types of firm relocation and attraction efforts (such as tax abatements) ranges from $\$ 11,000$ to $\$ 50,588$ [71].

While this clearly suggests that incubators can be a low-cost way to create new small businesses and hence jobs, in inner city areas some important caveats remain. First, extant evaluation research still has not been able to provide longitudinal assessments of the outcomes of incubators, in part because of problems tracking incubated firms and also due to the difficulties in creating necessary counterfactuals: how would firms have fared if they had not been incubated [72]. It is also important to remember that even to the extent that incubators create individual wealth for owners, stimulate business innovations, and increase stability in the areas in which they are located, the number of jobs they produce remains relatively small. In addition, most incubators (about two-thirds according 
to some studies) are not self-sustaining and will not become so for at least ten years [73]. Thus, incubators need to be viewed as a publicly supported community development technique, not as a potentially revenue-generating enterprise.

Recent evaluations of business incubators supported by the federal US Economic Development Administration have suggested that the following factors are critical to ensuring that incubators contribute to long-term sustainability more consistently [74].

- Incubators should specialize in certain types of tenant firms: high tech, craft, those needing only office or administrative services, health related and so on.

- There need to be clearly established time limits for how long firms can remain in the incubator to ensure that new businesses can enter.

- Incubators need to be combined with programmes that provide start-up and operating capital for fledgling businesses such as small business or revolving loan programmes.

- Incubators are more successful when combined with other local development efforts such as industrial parks, historic district renovation, skill training programmes, and loan programmes.

- Incubators need the support of public revenues for both initial infrastructure and continued operation of business support services over the long term.

\subsubsection{Faith-based initiatives}

Over the past thirty years there has been a dramatic transformation in the way North American political processes operate. One particularly important structural change is an increased tendency to separate funding from the design and implementation of public policy [75]. While this has typically taken the form of state/provincial and local implementation of public programmes with federal funding, it has also involved service provision by private and non-profit organizations using public funds. Faith-based service provision (i.e. services provided by religious organizations and/or congregations) is a logical extension of both 'reinvention' of government - through a focus on ends-oriented governance - and 'devolution', as federal and subfederal actors are replaced by faith-based organizations (FBOs) [76]. FBOs are often seen as efficient actors, highly motivated to serve 'customers' and able to impact long-term behaviour in ways not possible for traditional public agencies.

Faith-based institutions or 'communities' have unique resources to bring to the task of sustaining inner city areas and residents: they tend to be among the few significant and viable institutions still located in many inner city neighbourhoods; community service has been a primary value or focus of most of the world's major religions; urban religious institutions have significant organizational and leadership resources which can be brought to bear; and faith-based efforts can address not only the financial problems of inner city areas but more spiritual ones as well [77, 78].

FBOs have been active in community and economic development efforts, traditionally focusing on housing. However, case studies indicate some limited activity in job and entrepreneurial training, business incubators, consulting support, credit unions, and both individual and business loans [77, 79-84]. Faith-based entrepreneurial efforts in the cities of Boston, Detroit, New York, Oakland, and Chicago have included cooperative restaurants, operation of restaurant franchises such as McDonald's and Kentucky Fried Chicken, construction cooperatives, rehabilitation of former 'crack' houses, recycling operations, auto shops, credit unions, print shops, job information centres, and day care centres [78, 80, 83, 85, 86]. Faith-based community development efforts in a number of other cities range from low- and middle-income housing development to credit unions to provide start-up financing to minority businesses and to the development of a community supermarket [77].

Faith-based efforts appear most prevalent among certain types of congregations - larger and wealthier African American congregations in particular. Indeed it has been suggested that African American churches are likely to take on the role of public service provider 'because a black political ethos and 
black public opinions about political participation guides them, the material incentives of public policies entice them, and the substantive needs of their neighbourhoods compels them' [87]. This quote highlights the unique contributions that faith-based development efforts, particularly in inner cities, might make to long-term community sustainability. They are inherently community based, operate from the bottom up, rest on institutions and cultures that are historically integral to the community, and the added element of faith may lead to success where secular or private sector initiatives have failed.

However, there are a number of questions about the viability of FBOs as economic development engines. First, it appears that while the scope of activity related to community development appears to be broad, the actual number of FBOs engaging in community development services and activities is much more limited. Many congregations cooperate with neighbourhood or other church-based efforts rather than engaging in programmes on their own. Facing the resource demands required, volunteer efforts of congregants have limited sustainability over the long term, and there are often conflicts between the religious roles of FBOs and their roles as implementers of publicly funded programmes $[88,89]$. More critically, given the dearth of evaluations of the outcomes of faith-based development efforts, their relative level of success vis-à-vis traditional government efforts remains a matter of 'faith'.

While sufficient research exists on the other types of development strategies discussed in this article to posit recommendations, the jury is still very much out on faith-based strategies. Rather, research has posed more questions than answers [89]:

- What is the proper relationship between the church and the state, particularly with regard to public funding of faith-based service provision?

- What is the nature and extent of faith-based service delivery, particularly in comparison to the activities of other types of organizations?

- What types of social service activities have faith-based institutions conducted? Are complete services being provided or are FBOs better suited to particular aspects of services? What clienteles are served by the social and community development services of religious institutions?

- How do the activities of faith-based and governmental organizations compare? Do a sufficient number of FBOs have the long-term organizational and administrative capacities to act as viable alternatives or even complementary social service providers?

- What does the element of 'faith' contribute to faith-based efforts in comparison with the service efforts of secular organizations?

- How does the inclusion of FBOs in the network of service providers affect the overall distribution of political influence and power in a community?

4.3.3 Tax increment financing

Tax increment financing (TIF) districts for redevelopment provide a mechanism through which increases in property tax revenue resulting from rising property values or new construction are captured to support locally determined maintenance and improvement strategies. The typical process to create a TIF would be as follows: an area is designated as a TIF district; the base property value in the area is established and held constant (typically for more than 20 years); the TIF authority invests in improvements in the area (infrastructure, site assembly, subsidized business financing, and so on); and property values increase due to these improvements. The difference between the frozen assessment and the increased value is invested back into the TIF district or used to pay off debt from initial investments.

The use of TIFs is very common across the US in particular; 49 states use or allow the use of such financing, making it one of the most popular economic development tools, and its use has increased steadily since the 1970s [90,91]. Part of its popularity lies in the presumptive development benefits of TIFs. Municipalities do not have to increase taxes to support development or divert other revenues. 
TIF allows for increased revenue growth to support redevelopment in targeted areas of blight or financial need [92].

Research on the use of TIFs for business development and downtown redevelopment has indicated that they tend to increase local revenues and reduce property tax rates generally through increased investment [93,94]. However, it may take many years for property value increases to pay off initial investments, and TIFs often cause overlapping tax jurisdictions, like school districts, to have to raise taxes to cover lost revenue diverted to the TIF [92, 93, 95, 96].

A potentially more sustainable form of TIF would be those established in residential neighbourhoods and directed at community rather than business development. In cities where property values are rising rapidly, but demands on the public sector are increasing even more rapidly, the neighbourhood TIF provides a means to ensure that a 'fair share' of new revenues is returned to the neighbourhood from which the increase is generated. Neighbourhood TIFs often have goals in addition to the common aims (job creation and business investment) of more traditional business-related TIFs, including developing housing, building social capital, and improving the general quality of life for residents of the TIF that directly contributes to sustainable communities. As a result, neighbourhood TIFs may mitigate the tax diversion effects on other local units by directing revenue toward the community generally rather than to individual businesses [97].

A recent analysis of the design and implementation of TIFs across the US made the following recommendations for their use [97]:

- In general, enabling legislation should encourage the use of TIF districts to be limited and strategic rather than widespread.

- The use of TIFs should be limited to distressed communities although not necessarily to distressed locations within those communities.

- Areas that are severely distressed may not be the most appropriate choice for a TIF designed to promote neighbourhood revitalization.

- Enabling legislation should identify and vary according to different types of TIFs (e.g. Brownfield, commercial, neighbourhood).

- Outcome reporting requirements should be required in the governance structure.

- The original nature of the TIF, i.e. what types of development are allowed, matters as far as outcomes; residential designation leads to housing units, industrial TIFs produce new jobs, and all other types of TIFs are associated with increased property values.

- Public participation in governance of neighbourhood TIFs is essential.

- Neighbourhood TIFs in particular are likely to require 'seed' money in their initial years since they are unlikely to have large new investment projects to provide an immediate increase in taxable values.

Ultimately, the success of neighbourhood TIFs will depend on the extent to which anticipated private investment occurs to drive up values and generate funds necessary for planned improvements. Clearly, TIFs are not a panacea. But, if used judicially, they can provide a useful mechanism to address both neighbourhood and developer needs in central cities. Even under the most favourable circumstances, with respect to state enabling legislation and local planning and organization of TIF activities, there is no guarantee that the market will be cooperative. But there is some indication that the odds of success can be improved by the choices that are made [97].

\section{CONCLUSIONS}

There are several conclusions that can be drawn from this meta-analysis of literature on sustainable local development policies in North America. Overall, it seems that the widespread sustainability of North America's urban areas remains an elusive goal. With few exceptions, the patterns of urban 
development continue in much the same way as they have for the past six decades. Land and other limited resources continue to be consumed at high rates by peripheral growth around every metropolitan area, while many older city centres and neighbourhoods continue to erode.

The predominant form of urban growth continues to be inconsistent with present and future sustainability. Large areas of low density and homogeneous (single land use) development are wasteful of land as well as being difficult and expensive to serve with public services. Such growth often impacts agricultural and other environmentally important resources. Moreover, the continuation of sprawling development is creating vast areas where more sustainable (higher density, mixed use) development will be more difficult to attain through redevelopment.

As suggested above, North American urban areas can at least move toward sustainability if a new model of development is adopted, one that simultaneously incorporates best practices for managing the expansion of the urbanized area while making older areas more competitive through revitalization efforts. The examples presented in this paper suggest that the means to this end are already being applied in limited cases, although questions obviously remain regarding their most effective implementation. Indeed, there are some indications that a more sustainable paradigm for urban development is gaining increased acceptance; implementation of urban growth boundaries in Portland, tax base sharing in Minnesota, and the use of new business incubators across the US bears out this supposition.

There are other indications that there is at least a growing awareness of the value of sustainable development paradigms. Neo-traditional developments, incorporating higher densities and mixed uses, have proven to be popular even in outlying suburban locations [98, 99]. The high costs of utility extensions (coupled with growing resistance to increasing taxes) and gasoline have produced a decline in the market for new development in exurban areas. And, even in strong home rule and property rights states like Michigan, there has been bipartisan support for initiatives that reflect the importance of regional approaches to sustainable development [100].

Central city revitalization initiatives have also gained wider acceptance in recent years. Some of the most common public revitalization programmes (sports facilities, casinos and other entertainment venues, and industrial incentives) have proven to be relatively expensive in terms of public subsidies and have produced few spin-off benefits. Community-based initiatives such as business incubators, neighbourhood TIF districts, and faith-based economic development may be more sustainable but their potential to be scaled up to achieve higher levels of impact is not yet clear.

Demographic trends and individual preferences may in the long run have a greater impact on central city sustainability. Immigration seems likely to continue to contribute to the resurgence of central city populations as it has done for the last two decades [101]. Changing household arrangements and lifestyle preferences will continue to contribute to the demand for housing in downtown and trendy neighbourhoods.

Still, sustainable metropolitan growth management continues to be far from a reality in most metropolitan areas. With notable exceptions, such as Portland and Vancouver, North American urban areas continue to expand their geographic footprint, even if there is little or no growth in population or households. It is evident that there is little commitment to the structural changes required to achieve the type of managed growth that will truly enhance sustainability.

Thus, the outcome of the struggle for metropolitan sustainability is not at all clear. There are a number of encouraging trends, including a growing number of voices echoing Jane Jacobs' call for more sensible sustainable urban areas. But it would appear that most individual and corporate decision makers continue to prefer low-density, new development. Increased individual commitment to sustainability is unlikely to be sufficient; what will be required is increased political will to implement the more extensive government reorganization and growth management policies most likely to lead to long-term sustainable development, i.e. development that meets economic needs now while not endangering the future quality of life in urban areas. 


\section{REFERENCES}

[1] Fulton, W., The Reluctant Metropolis: The Politics of Urban Growth in Los Angeles, Solano: Point Arena, 1997.

[2] Innes, J.E. \& Booher, D.E., Metropolitan development as a complex system: a new approach to sustainability. Economic Development Quarterly, 13, pp. 141-156, 1999.

[3] Filion, P. \& Hoernig, H., Downtown past, downtown present and downtown yet to come. Plan, Spring, pp. 3-6, 2003.

[4] Orfield, M., American Metropolitics, Brookings: Washington, DC, 2002.

[5] Leland, S. \& Thurmaier, K., Reshaping the Local Government Landscape: Case Studies of Local Government Consolidation, M.E. Sharp: New York, 2004.

[6] Carr, J.B. \& Feiock, R.C., Perspectives on City-Consolidation and Its Alternatives, M.E. Sharp: New York, 2005.

[7] Savitch, H.V. \& Vogel, R.K., Suburbs without a city: power and city-county consolidation. Urban Affairs Review, 39, pp. 758-790, 2004.

[8] Reese, L.A. \& Rosenfeld, R.A., Local economic development in the U.S. and Canada: institutionalizing policy approaches. The American Review of Public Administration, 34, pp. 277292, 2004.

[9] Reese, L.A. \& Sands, G., Making the least of our differences? A panel study of Canadian and US local economic development. Canadian Public Administration, forthcoming.

[10] Rusk, D., Cities without Suburbs, Woodrow Wilson Center Press: Washington, DC, 1993.

[11] Roberts, B. \& Cohen, M., Enhancing sustainable development by triple value adding to the core business of government. Economic Development Quarterly, 16, pp. 127-137, 2002.

[12] Hawkin, P., Lovins, A. \& Lovins, L., Natural Capitalism: The Next Industrial Revolution, Earthscan: London, 1999.

[13] Colgan, C.S., 'Sustainable development' and economic development policy: lessons from Canada. Economic Development Quarterly, 11, pp. 123-137, 1997.

[14] World Commission on Environment and Development, Our Common Future, Oxford University Press: New York, 1987.

[15] Staley, S.R. \& Mildner, G.C.S., Urban-Growth Boundaries and Housing Affordability: Lessons from Portland, Reason Public Policy Institute: Los Angeles, 1999.

[16] Bunting, T.E. \& Filion, P., The Canadian City in Transition: The Twenty First Century, Oxford University Press: Toronto, 2000.

[17] Randall, R., U.S. and Canadian urban vitality a metropolitan analysis. Paper presented at the annual meeting of the Urban Affairs Association, New Orleans, Louisiana, March 1994.

[18] Rothblatt, D.N., North American metropolitan planning: Canadian and U.S. perspectives. Journal of the American Planning Association, 60, pp. 501-520, 1994.

[19] Filion, P., Bunting, T. \& Gertler, L., Cities and transition: changing patterns of urban growth and form in Canada. Canadian Cities in Transition, eds T. Bunting \& P. Filion, Oxford: New York, 2000.

[20] Simmons, J. \& McCann, L., Growth and transition in the Canadian urban system. Canadian Cities in Transition, eds T. Bunting \& P. Filion, Oxford: New York, 2000.

[21] Lindstrom, B., Regional Cooperation and Sustainable Growth: A Study of Nine Councils of Government in the Northeastern Illinois Region, Great Cities Institute: Chicago, 1997.

[22] National Association of Development Organizations (NADO), State Association of Regional Councils of Government and Regional Development Organizations: Insights into Organizations Structures, Governance Models and Strategic Initiatives, NADO: Washington, DC, 2005. 
[23] Miller, G.J., Cities by Contract: The Politics of Municipal Incorporation, MIT Press: Cambridge, 1981.

[24] LeRoux, K.M. \& Carr, J.B., The social structure of interlocal cooperation in metropolitan areas. Paper presented at the annual meeting, Midwest Political Science Association, Chicago, April 2005.

[25] Collins, S., Interlocal Service-Sharing Agreements IQ Report, ICMA: Washington, DC, 2006.

[26] Hinze, S. \& Baker, K., The fiscal disparities program: commercial-industrial tax base sharing. www.house.mn/hrd/hrd.htm, 2005.

[27] Rusk, D., Inside Game, Outside Game, Brookings Institution: Washington, DC, 2001.

[28] Savitch, H.V. \& Thomas, J.C., Big City Politics in Transition, Sage Publications: Thousand Oaks, 1991.

[29] Sancton, A. Differing approaches to municipal restructuring in Montreal and Toronto: from the Pichette report to the greater Toronto services board. Canadian Journal of Regional Science, Spring/Summer, pp. 187-199, 1999.

[30] Harrigan, J.J. \& Vogel, R.K., Political Change in the Metropolis, Longman: New York, 2003.

[31] Stein, D.L., Is there life after metro? Planning, March, pp. 11-15, 1995.

[32] Turner, R., Tropical heat: lessons in Miami politics. Urban News: Newsletter of the Urban Politics Section, 12(1), pp. 1, 2, 4, 6-10, 1998.

[33] Rosenfeld, R.A. \& Reese, L.A., Local government amalgamation from the top-down. Perspectives on City-Consolidation and Its Alternatives, eds J. Carr \& R. Feiock, M.E. Sharp: New York, 2004.

[34] Blodgett, T., Current City-County Consolidation Attempts, National Association of Counties: Washington, DC, 1996.

[35] Leland, S. \& Cannon, C., Metropolitan city-county consolidation: is there a recipe for success? Paper presented at the annual meeting, Midwest Political Science Association, Chicago, April 1997.

[36] Durning, D., The effect of city-county government consolidation: the perspectives of united government employees in Athens-Clarke County, Georgia. Public Administration Quarterly, Fall, pp. 272-298, 1995.

[37] Razin, E. \& Rosentraub, M., Are fragmentation and sprawl interlinked? North American evidence. Urban Affairs Review, 35, pp. 821-836, 2000.

[38] Vojnovic, I., The transitional impacts of municipal consolidation. Journal of Urban Affairs, 22, pp. 385-417, 2000.

[39] Nelson, M., Municipal amalgamation and the growth of the local public sector in Sweden. Journal of Regional Science, 32, pp. 39-53, 1992.

[40] O'Brien, A., Municipal Consolidation in Canada and Its Alternatives, ICURR Publications: Toronto, 1993.

[41] Reese, L.A., Metropolitan reorganization: same governance, different day? The Review of Policy Research, 21, pp. 595-611, 2004.

[42] Nelson, A.C. \& Foster, K.A., Metropolitan governance structure and income growth. Journal of Urban Affairs, 21, pp. 309-324, 1999.

[43] Carr, J.B. \& Feiock, R.C., Metropolitan government and economic development. Urban Affairs Review, 34, pp. 476-488, 1999.

[44] Wolfson, J. \& Frisken, F., Local response to the global challenge: comparing economic development policies in a regional context. Journal of Urban Affairs, 22, pp. 361-384, 2000.

[45] Post, S.S. \& Stein, R.M., State economies, metropolitan governance, and urban-suburban economic dependence. Urban Affairs Review, 36, pp. 46-60, 2000.

[46] Dittmer, H. \& Ohlend, G., The New Transit Town, The Island Press: Washington, DC, 2004. 
[47] Reese, L.A. \& Sands, G., The equity impacts of municipal tax incentives: leveling or tilting the playing field? Review of Policy Research, 23(1), pp. 71-94, 2006.

[48] Burayidi, M., Downtowns: Revitalizing the Centres of Small Communities, Routledge: New York, 2001.

[49] Seasons, M., Is urban revitalization good for cities? Yes, if properly planned. Plan, Spring, pp. 26-27, 2003.

[50] Gad, G. \& Matthew, M., Central and suburban downtowns. Canadian Cities in Transition, eds T. Bunting \& P. Filion, Oxford: New York, 2000.

[51] Salvasen, D., A catalyst for redevelopment. Urban Land, 58(11/12), pp. 67-81, 1999.

[52] McMahon, K. \& Cohill, A., Get wired or get left behind. Planning, July, pp. 4-9, 2003.

[53] Sands, G., No finer place: planning care areas in mid-sized Canadian cities. International Journal of Sustainable Planning and Development, forthcoming.

[54] Filion, P., Hoernig, H., Bunting, T. \& Sands, G., The successful few: healthy downtowns and small metropolitan regions. Journal of the American Planning Association, 70, pp. 328-343, 2004.

[55] Knack, R., Downtown is where the living is easy. Planning, 64, pp. 4-9, 1998.

[56] Birch, E., Having a longer view of downtown living. Journal of the American Planning Association, 68, pp. 5-21, 2002.

[57] Lang, R.E. \& LeFurgy, J., Edgeless cities. Urban Land, 63(1), pp. 40-43, 2004.

[58] Peters, A. \& Fisher, P., The failures of economic development incentives. Journal of the American Planning Association, 70, pp. 27-37, 2004.

[59] Sands, G., Reese, L.A. \& Kahn, H.L., Implementing tax abatements in Michigan: a study of best practices. Economic Development Quarterly, 20, pp. 44-58, 2006.

[60] Reese, L.A. \& Malmer, A., The effects of state enabling legislation on local economic development policies. Urban Affairs Quarterly, September, pp. 114-135, 1994.

[61] Sands, G. \& Zalmezak, P., Michigan industrial property tax abatements: a summary of activity under Public Act 198 of 1974, 1985-98. Paper presented at the Urban Research Seminar, Detroit, MI, 2001.

[62] Due, J., Studies of state-local tax influences on location of industry. National Tax Journal, 14, pp. 163-173, 1961.

[63] Ahlbrandt, R.S. \& DeAngelis, J.P., Local options for economic development in a maturing industrial region. Economic Development Quarterly, 1, pp. 41-51, 1987.

[64] Schwarz, J.E. \& Volgy, T.J., The impacts of economic development strategies on wages: exploring the effect on public policy at the local level. Paper presented at the annual meeting of the American Political Science Association, Chicago, September 1992.

[65] Fisher, P.S. \& Peters, A.H., Industrial Incentives: Competition among American State and Cities, W.E. Upjohn Institute for Employment Research: Kalamazoo, 1998.

[66] Campbell, C. \& Allen, D.A., The small business incubator industry: micro-level economic development. Economic Development Quarterly, 1, pp. 178-189, 1987.

[67] National Business Incubator Association (NBIA), 10th Anniversary Survey of Business Incubators: 1985-1995, NBIA: Athens, 1996.

[68] Sherman, H. \& Chappell, D.S., Methodological challenges in evaluating business incubator outcomes. Economic Development Quarterly, 12, pp. 313-321, 1998.

[69] Lyons, T., Birthing Economic Development: How Effective Are Michigan's Incubators? Center for the Redevelopment of Industrialized States, Social Science Research Bureau, Michigan State University, East Lansing, 1990.

[70] Tornatzky, L., Batts, Y., McCrea, N., Lewis, M. \& Quittman, L., The Art and Craft of Technology Business Incubation: Best Practices, Strategies and Tools from 50 Programs, Southern 
Technology Council, National Business Incubation Association, and the Ohio Institute for Local Government Administration and Rural Development, Athens, 1995.

[71] Markley, D.M. \& McNamara, K.T., Economic and fiscal impacts of a business incubator. Economic Development Quarterly, 9, pp. 273-278, 1995.

[72] Bearse, P., A question of evaluation: NBIA's impact assessment of business incubators. Economic Development Quarterly, 12, pp. 322-333, 1998.

[73] National Business Incubator Association (NBIA), The State of the Business Incubator Industry, 1991, NBIA: Athens, 1992.

[74] Fasenfest, D., Reese, L.A., Rosenfeld, R.A. \& Case, P., Evaluation of the Impact of EDA Economic Adjustment Program Investments, US Department of Commerce: Washington, DC, 2005.

[75] Hula, R.C., \& Jackson-Elmoore, C., Governing nonprofits and local political processes. Urban Affairs Review, 36(3), pp. 324-358, 2001.

[76] Jensen, L.S., Not by bureaucracy alone: charitable choice and the reinvention of church as state. Paper presented at the annual meeting, New England Political Science Association, May, 2001.

[77] Cisneros, H.G., Higher Ground: Faith Communities and Community Building, US Department of Housing and Urban Development: Washington, DC, 1996.

[78] Thomas, J.M. \& Blake, R.N., Faith-based community development and African-American neighbourhoods. Revitalizing Urban Neighbourhoods, eds W.D. Keating, N. Krumholz \& P. Star, pp. 131-143, University Press of Kansas: Lawrence, 1996.

[79] Hodgkinson, V.A., Weitzman, M. \& Kirsch, A., From Belief to Commitment: The Activities and Finances of Religious Congregations in the United States, Independent Sector: Washington, DC, 1988.

[80] Lincoln, C.E. \& Mamiya, L.H., The Black Church in the African American Experience, Duke University Press: Durham, 1990.

[81] La Barbera, P.A., Enterprise in religious-based organizations. Nonprofit and Voluntary Sector Quarterly, 21, Spring, pp. 51-67, 1992.

[82] Mares, A.S., Housing and the church. Nonprofit and Voluntary Sector Quarterly, 23, Summer, pp. 139-157, 1994.

[83] Heim, S.M., God's long shot in the inner city: a vision of church-based economic development. Christian Century, July, pp. 680-682, 1995.

[84] Reese, L.A. \& Shields, G., Economic development activities of urban religious institutions. International Journal of Economic Development, 2, pp. 165-199, 1999.

[85] Gordon, W. \& Frame, R., Real Hope in Chicago: The Incredible Story of How the Gospel is Transforming a Chicago Neighbourhood, Zondervan: Grand Rapids, 1995.

[86] Sherman, A.L., Cross Purposes: Will conservative welfare reform corrupt religious charities? Heritage Policy Review, 74, Fall, Online posting, 1995.

[87] Owens, M.L., Politics by other means: urban black churches, community development corporations, and public policy. Paper presented at the annual meeting, American Political Science Association, August 2003.

[88] Reese, L.A. \& Shields, G., Faith-based economic development: characteristics of active churches. Policy Studies Review, 17, pp. 84-103, 2000.

[89] Hula, R.C., Jackson-Elmoore, C. \& Reese, L.A., Mixing god's work and the public business: an exploration of faith-based service delivery. Journal of Policy Research, forthcoming.

[90] Johnson, C.L. \& Kriz, K., A review of state tax increment financing laws. Tax Increment Financing and Economic Development: Uses, Structures, and Impact, eds C.L. Johnson \& J.Y. Man, pp. 31-56, State University of New York Press: Albany, 2001. 
[91] Johnson, C.L. \& Man, J.Y., Tax Increment Financing and Economic Development: Uses, Structures, and Impact, State University of New York Press: Albany, 2001.

[92] Weber, R., Equity and entrepreneurialism the impact of tax increment financing on school finance. Urban Affairs Review, 38, pp. 619-644, 2003.

[93] Huddleston, J., Distribution of development costs under tax increment financing. Journal of the American Planning Association, 52, pp. 194-198, 1986.

[94] Lawrence, D. \& Stephenson, S., The economic and politics of tax increment financing. Growth and Change, 26, pp. 105-137, 1995.

[95] Stinson, T., Subsidizing local economic development through tax increment financing. Policy Studies Journal, 20, pp. 241-248, 1992.

[96] Lehnan, R. \& Johnson, C., The impact of tax increment financing on school districts: an Indiana case study. Tax Increment Financing and Economic Development: Uses, Structures, and Impact, eds C. Johnson \& J.Y. Man, State University of New York Press: Albany, 2001.

[97] Trudeau, K., Reese, L.A. \& Sands, G., Tips for TIFS: Outcomes and success predictors for neighborhood TIFS, presented at the annual meeting, Association of Collegiate Schools of Planning, Kansas City, October 2005.

[98] Hall, K.B. \& Porterfield, G.A., Community by Design, McGraw-Hill: New York, 2001.

[99] Grant, J., Planning the Good Community, Routledge: London, 2006.

[100] Michigan Land Use Leadership Council (MLULC), Michigan's Land, Michigan's Future, www.michiganlanduse.org, 2003.

[101] Joint Center for Housing Studies (JCHS), State of the Nation's Housing 2006, http://www. jchs.harvard.edu/publications/markets/son2006/index.htm, Harvard University: Cambridge, 2006. 